\title{
Environmental Education and Energy Efficiency as Strategies for Reducing Energy Consumption in Public School Building in Goiânia
}

\author{
Marlison Noronha Rosa* \\ *Escola de Engenharia Civil e Ambiental, Universidade Federal de Goiás, Goiânia, Brazil. \\ E-mail: marlison.rosa@hotmail.com \\ Yan Machado Sousa \\ •Escola de Engenharia Civil e Ambiental, Universidade Federal de Goiás, Goiânia, Brazil. \\ E-mail: yan_doyathang@hotmail.com \\ Karla Emmanuela Ribeiro Hora \\ `Escola de Engenharia Civil e Ambiental, Universidade Federal de Goiás, Goiânia, Brazil. \\ E-mail: karlaemmanuela@gmail.com \\ Katia Kopp \\ 'Escola de Engenharia Civil e Ambiental, Universidade Federal de Goiás, Goiânia, Brazil. \\ E-mail: kakopp@gmail.com \\ Getúlio Antero de Deus Junior ${ }^{\circ}$ \\ ${ }^{\circ}$ Escola de Engenharia Elétrica, Mecânica e Computação, Universidade Federal de Goiás, \\ Goiânia, Brazil. \\ E-mail: gdeusjr@ufg.br
}




\author{
Camilo Rosales ${ }^{\downarrow}$ \\ ${ }^{\downarrow}$ Florida Internacional University, Florida, United States of America. \\ E-mail: rosalesc@gmail.com
}

\begin{abstract}
Electrical energy is essential for the quality of life of people, who use it in different socioeconomic activities and for technological development. In view of the gradual increase in the demand for electricity and the future possibility of not serving all the consumer sectors, it is necessary to optimize it. The objective of this study was the application of strategies based on the pillars of energy efficiency and environmental education in order to minimize the expenditure of electric energy in public buildings, which were selected for this project due to the fact that, its users show a lack of concern about the correct consumption of electric energy since the expenses are tied to the public coffers and are not always perceived by the people as resources coming from the taxes paid by the citizens. Among the public buildings that consume the most electric energy, the most important are those in the Education Sector. In fact, a larger project called the Energy Efficiency Project in Public Buildings in Goiânia (PEEEPG), to which this work is linked, found that among the municipal public buildings, the education sector is responsible for approximately $30 \%$ of the electricity consumption and, therefore, this specific sector was selected for the application of the selected strategies. The methodology used was based on research-participant, environmental education together with replacement of lamps by LED system (Light Emitting Diode) at strategic locations in the building and monitoring of results. The actions carried out included the lamp replacement, and educational lectures offered to students of different age groups in three school shifts with a partnership of employees and teachers of the municipal school selected on energy efficiency and strategies to reduce the consumption of electricity. The project mobilized directly about 200 people belonging to the target audience and indirectly 800 students who were part of the teaching unit. It was collected a data base among 2012 to 2016. The methods of data collection and analysis were based on documentary research, analyzing the electric energy bills of the building, as well as documents and legislation of the municipality itself on the consumption of electric power and the architecture model applied to school environments in Goiânia. The results obtained, after a monitoring period of six months (November to April) during the years 2016 and 2017, indicated an analyze to reduction of $16 \%$ of the consumption of electric energy in the building, compared to the same period in the previous year. Therefore, this result regard to the possibility of investments in energy efficiency projects for public buildings, subsidizing actions in the design, retrofit and maintenance of public buildings.
\end{abstract}

Keywords: Electricity Consumption, Energy Efficiency, Environmental Education, Light Emitting Diode, Public Buildings. 


\section{Introduction}

Energy is fundamental for both the productive means and the improvement of the quality of people's lives, regardless of their use: motor power, heating, cooling, lighting, mobility. Moreover, this dependence is verified, not only for survival, but also for the socioeconomic and technological improvement of civilization. The post-oil crisis scenario, beginning in 1973, reflected changes in public policy and increased concerns about the current economic, social, and ecological development model ${ }^{1,2}$.

The increase in the use of electric energy, for example, in recent years was directly related to factors such as economic and population growth, urbanization process, industrialization and intensification of new consumption patterns. The graphic in Figure 1 shows the per capita energy consumption in some countries between 1970 and 2009, illustrating the gradual increase in consumption in developed countries such as the United States and Australia, the world average, in addition to consumption in Brazil in Oil Equivalent Tonnes (OEP) ${ }^{3}$.

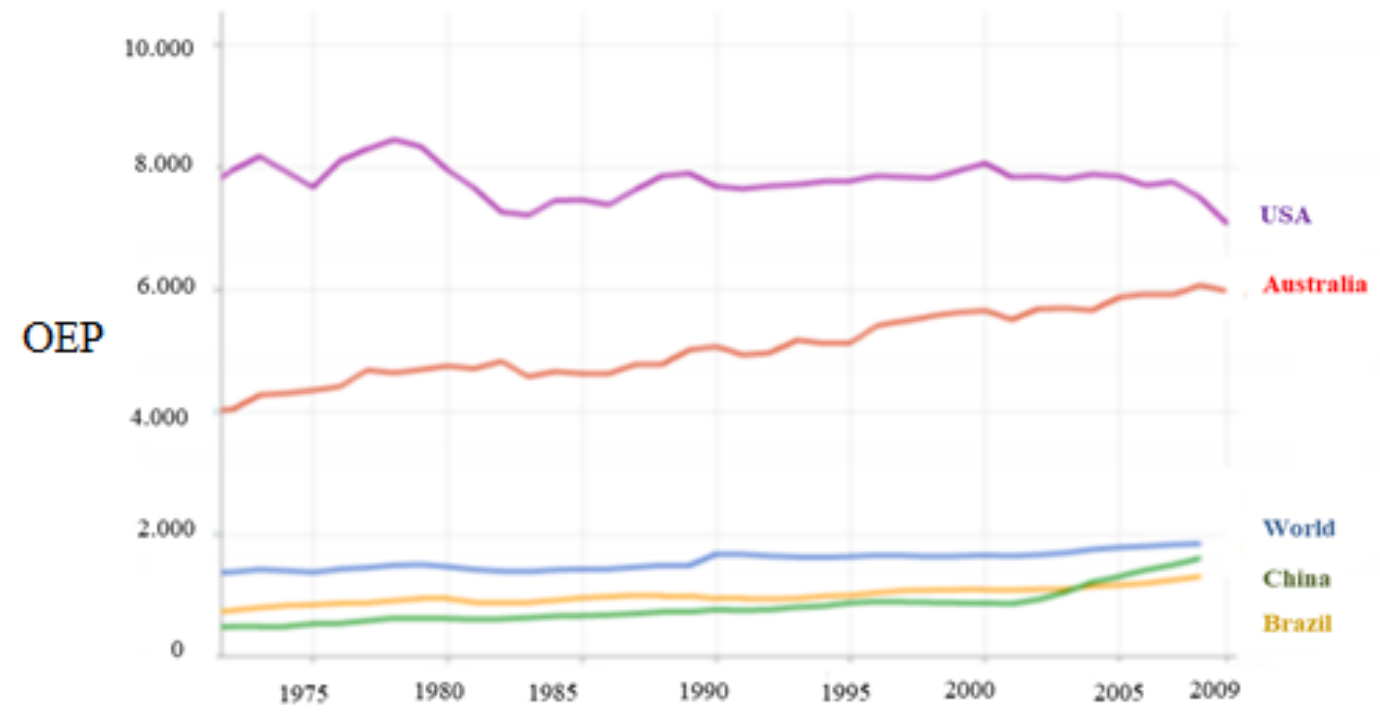

Figure 1. Energy use per capita in Equivalent Tonnes of Oil (TEP). Source: World Bank. World Development Indicators, 2010.

To reduce the increase in consumption, countries have invested in various programs aimed at avoiding a possible energy crisis. In view of the growth in energy consumption, countries have set up specific institutions to address energy efficiency, such as stimulating the use of renewable energy sources and incentives to deploy more efficient systems. In developed countries such as the USA, Canada and Australia, they encourage energy management in companies by providing various tools that help implement energy management in a company, including the technological, organizational and behavioral dimensions ${ }^{1,4}$.

In this context, Brazil is identified as one of the precursors to the development of efficient energy alternatives, as well as the implementation of instruments that allow the use of energy in a correct way, not only for public buildings, but throughout the entire production and energy consumption level ${ }^{5}$.

Energy efficiency has become increasingly present in the discussions on energy demand at the global level, involving the various factors that contextualize energy production to the 
final availability to users, in which there is a preponderant focus on world energy and energy policies. especially in those related to climate change ${ }^{6}$.

It is worth mentioning that this work was part of a project of Energy Efficiency in Public Buildings of Goiânia (PEEEPG), executed in partnership by the Universidade Federal de Goiás (UFG), Prefeitura de Goiânia and International University of Florida, with funding from the US State Department. The project had an execution period of 2015 and lasted until March 2017.

\subsection{Energy Context in Brazil}

In the Brazil the electric energy crisis that occurred in 2001, called the Blackout Crisis, led the federal government to implement a rigorous rationing policy and pointed to the need for better policies and investments in the energy sector. Considering this context, Lamberts (2014) highlights the opportunity of investments in studies and proposals that allow the awareness of users and reduction of electric energy consumption based on energy efficiency and environmental education projects ${ }^{6}$.

According to the Energy Balance of $2017^{7}$, in the country, existing buildings accounted for $51.1 \%$ of electricity consumption, with the public accounting for $8.3 \%$. With the growing demand for electric energy in Brazil and the need to implement environmental sustainability practices, it is necessary to make efficient the use of the electric energy produced, as well as to encourage the rational consumption of it. Since energy generation depends on environmental conditions (renewable sources) and scarce resources (non-renewable sources) that can lead to a series of social and environmental impacts ${ }^{7}$.

In this context, different initiatives have been developed and improved to classify and measure energy costs in equipment and buildings, as well as to propose alternatives for a more sustainable energy consumption, such as the labeling programs for public equipment and buildings. For at least three decades Brazil has had Energy Efficiency programs. Since then, some have been recognized internationally. Indeed, the National Program for the Conservation of Electric Energy (Procel), the National Rationalization Program for the Use of Petroleum and Natural Gas Derivatives (Conpet) and the Brazilian Labeling Program (PBE), among others, in addition to specific policies and plans. In this way, the National Energy Conservation Label (ENCE) is the Seal of Compliance that evidences the fulfillment of performance requirements established in standards and technical regulations and in some cases additionally also of safety ${ }^{8}$.

The development of these programs provided a fundamental gain to the Brazilian scenario. From 2006 to 2013, the labeling of lamps was responsible for an economy of about $\mathrm{R} \$ 23$ billion. According to the Procel 2016 Results Report (base year 2015), electricity consumption in Brazil corresponded to 464.7 billion $\mathrm{kWh}$ in 2015 and, according to estimates, the program achieved an energy saving of 11.680 billion $\mathrm{kWh}$ compared the previous year ${ }^{9}$.

Brazilian Power Plants (Eletrobrás) invested in the period from 1986 to 2015 around $\mathrm{R} \$ 2.69$ billion in projects and actions of energy efficiency, reaching a saving of 92.2 billion $\mathrm{kWh}$. In view of these results, the importance of investments in programs in the energy context is highlighted ${ }^{10}$.

Among the strategies for the improvement of efficiency and thermal performance and consequent reduction of energy consumption in public buildings, are pointed out those that concern the energy demand derived from air conditioning and artificial lighting, responsible for the greater portion of consumption. In addition to the possibility of installing on-site power generation systems, such as the production of energy through photovoltaic solar panels that contributes to the energy supply of the building, other adaptations are important for 
improving comfort in buildings, such as use of vegetation near the building, cross ventilation and others, depending on local climatic conditions ${ }^{6}$.

The studies of Didoné et al. (2014) showed a contribution of around $38 \%$ of the generation of energy from solar panels. Considering the great availability of solar radiation in Brazil, this strategy becomes positive for the use of solar energy and application of photovoltaic technology in the country, and solar photovoltaic systems can be applied and/or integrated in the building and connected to the grid ${ }^{11}$.

However, to enable actions such as these, changes in habits and behavior in the daily attitudes and practices of both consumers and occupants of the buildings as well as political verdicts and investors becomes necessary. Understanding energy from its production and distribution limits can contribute to the efficient and moderate use of its sources and applications.

\subsection{Consumption of Energy at Municipal Public Buildings of Goiânia}

The municipality of Goiânia, the capital of the state of Goiás, in Brazil, is responsible for the highest consumption of electricity among the municipalities of the state, and in 2010, it had consumption of $2,525,294 \mathrm{MWh}$, according to data from the former company state, which underwent privatization in $2017^{12}$.

According to the Instituto Brasileiro de Geografia e Estatística (IBGE), the population growth of Goiânia represented $19.11 \%$ of the total growth of the State of Goiás between the years 2000 to 2010. According to Figure 2, the population evolution is presented ${ }^{13}$.
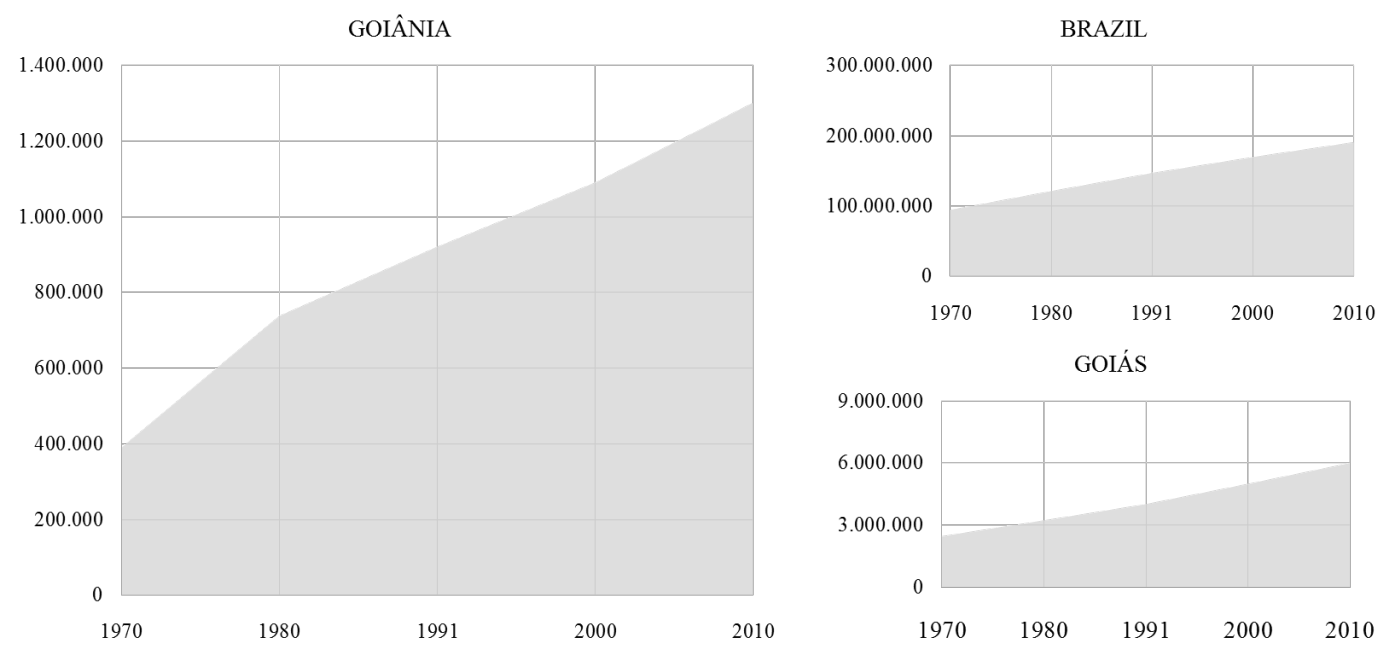

Figure 2. Population evolution of Goiás between 1991 and $2010^{13}$.

In the scope of this study, it was verified the differentiation of consumption in the different sectors of the Municipality of Goiânia and it was verified, through the survey of consumption of the municipal public buildings, in kilowatt hours, that the Education Sector corresponds to approximately $30 \%$ of the consumption of existing public buildings in different sectors. These data are easily explained since these are administrative units that have the largest built area and the largest number of buildings in the municipality ${ }^{14}$.

Acording with Hora et al.: "The need to optimize consumption and energy efficiency, concerns and actions to monitor energy consumption and guidelines to reduce its impact, the 
City of Goiânia has designated a Special Commission to identify the consumption situation and formulate proposals to contain and rationalize the use of electric power in the scope of the Administration of the Municipality of Goiânia, published in Decree Number 2132 of May 2001, whose participation was composed of representatives of seven municipal secretariats, as a consequence of a scenario of energy crisis that occurred in Brazil"14.

The energy consumption of the public buildings of the Municipality of Goiânia (PMG) in the years 2012 to 2015 increased by $5.8 \%$, as presented in Table 1 . Given the 731 consuming units (PA) in the PMG, in 2014, expenditures on electric energy of public buildings in the order of 12 billion reais ${ }^{14}$.

Table 1. Energy consumption of public buildings in Goiânia from 2012 to $2015^{14}$.

\begin{tabular}{|c|c|c|c|c|}
\hline Year & 2012 & 2013 & 2014 & 2015 \\
\hline Consumption $(\mathrm{kWh})$ & 20.990 .144 & 21.797 .057 & 21.992 .532 & 22.279 .659 \\
\hline Monthly Average $(\mathrm{kWh})$ & 1.749 .179 & 1.816 .421 & 1.832 .711 & 1.856 .638 \\
\hline
\end{tabular}

Thus, this study was based on the adoption of educational practices to reduce the consumption of electric energy by stimulating users by correctly using the resources available in a public education unit. In addition, it is known that the strategies in energy efficiency allow the reduction in costs, modernization and readjustment with the use of new equipment with greater performance and durability. In addition, efficiency actions can expand to 324 buildings existing in public education units in Goiânia.

\section{Purpose/Hypothesis}

The purpose of this study was to develop strategies to reduce the consumption of electric energy in a Municipal School of Goiânia by replacing lamps, environmental education actions and monitoring of results. In view of this, the following specific objectives were listed: analyze the consumption of electric energy in a public school building in Goiânia; develop strategies to reduce the consumption of electric energy through environmental education actions; monitor the reduction results in a given predetermined time interval; and as a hypothesis for the study, replacing lamps with more efficient ones associated with environmental education actions would result in a $10 \%$ to $15 \%$ reduction in the energy consumption of a public building in the education sector in Goiânia.

\section{Design/Method}

The study deals with a participant research, which proceeds from an alternative search to the standard of conventional research. Represented by Demo (1995) as a qualitative evaluation of social manifestations, committed to interventions that contemplate self-diagnosis (knowledge, accumulation and systematization of data) and consequent construction strategies to face practical problems detected. The characteristic of this process is shared knowledge between the parties, involving directly the researcher with the participants, in which the communicative action is the essence in the application of the $\operatorname{method}^{15}$.

In addition, the methodology used was based on environmental education programs based on replacement of lamps by LED systems (Light Emitting Diode) considering strategic locations in the building and monitoring of results. For the field research, the activities carried out were: visit to the selected building; collection of information necessary for the characterization of the building, contacts with the Municipal Department of Education; verification of prices and information to budget the interventions in the municipal education unit; and studies on intervention strategies to reduce energy consumption. 
The selected municipal education unit is in the Northwest Region of Goiânia, verified in Figure 3, being this one of the most deprived in socioeconomic terms of the city. The architectural design and construction model follow a "standard" typology adopted in several school units in the municipality. The school runs from Monday to Friday during the three periods of the day and counts on Basic Education (BE) and Educação de Jovens e Adultos $(\mathrm{EJA})^{14}$.

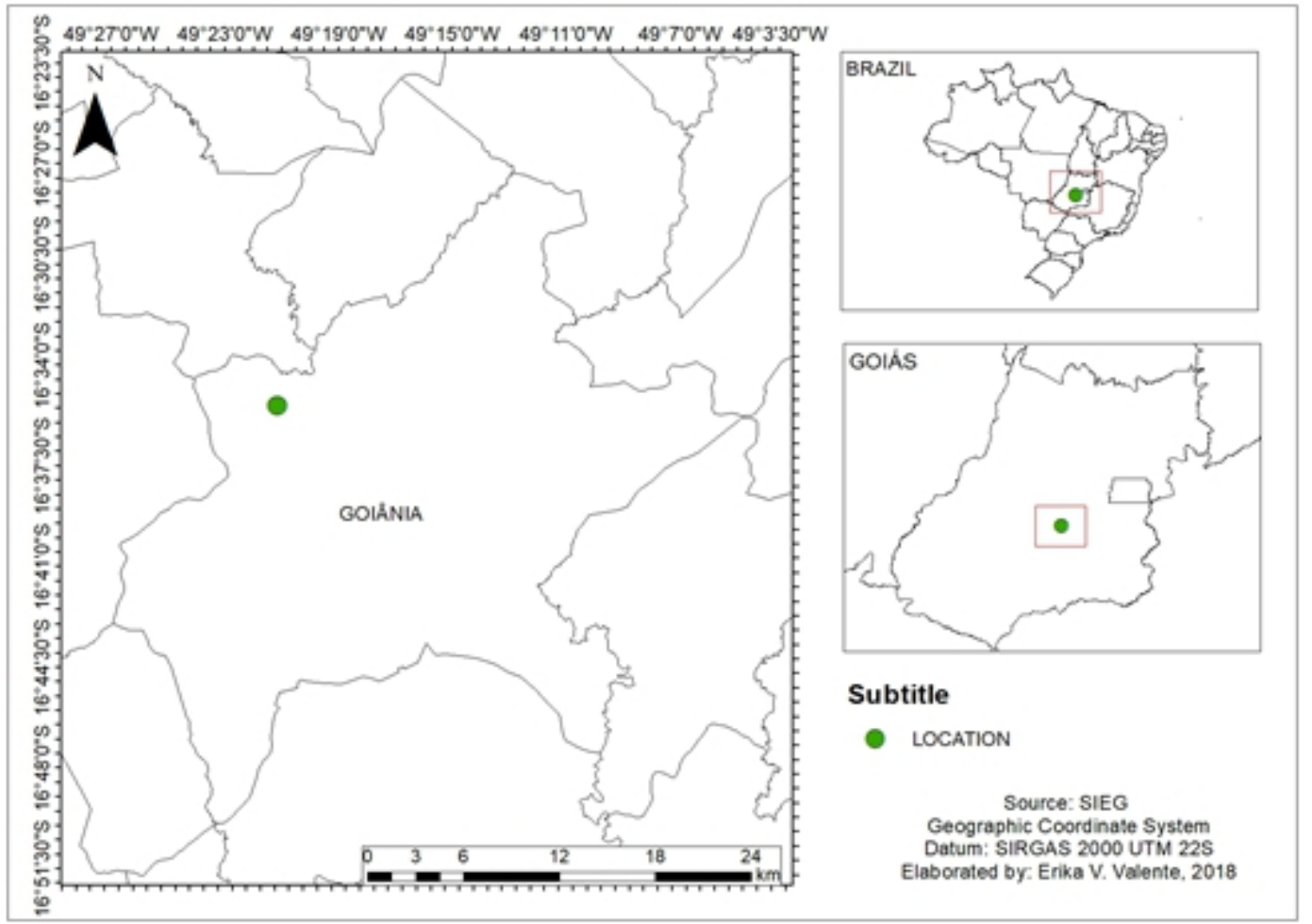

Figure 3. Location of the Northwest Region in Goiânia and indication of the Municipal Teaching Unit.

In view of this, actions were carried out together with the selected building, to evaluate the implemented strategies, in order to guarantee the reduction of energy consumption. For its development, the following steps were established: (I) bibliographic research; (II) documentary research; (III) characterization of the building under study; (IV) field research; (V) study for lamp replacement and in environmental education.

For the bibliographical research, articles of periodicals, dissertations, books specific to the subject under study, technical notes, research reports, theses and graduation studies were consulted. The methodology of the work was based on investigations of academic studies, which firstly pointed out strategies to reduce energy consumption. The research filter applied in the research focused on the use of keywords that addressed energy efficiency, environmental education, research-participant, as well as new trends in building performance that allowed harmonization of occupant comfort.

For documentary research, normative material, national legislation and the city of Goiânia, technical reports of public institutions and municipalities, database and the reports prepared in the field of the Energy Efficiency Project in Public Buildings of Goiânia 
(PEEEPG) were consulted. The records of consumption and energy bills between 2010 and 2016, in addition to architectural projects, were obtained from the municipal agencies of Goiânia (Municipal Department of Education and others) and State Electric Power Company to determine the consumption of the studied building.

In the characterization of the building selected for the study, the selection criteria considered were referring to the educational building with one of the largest electricity consumption in the municipality in the category, in order to increase the significance of the consumption reduction, in addition to the availability of the construction projects in digital format (dwg version), consumption data and energy bills for evaluation, besides being accessible for the application of the interventions proposed in the study.

The selection took place in April 2016, after contact with the responsible governmental body that indicated in which buildings the highest energy consumption was registered among the units of the municipality. In view of the parameters raised, the building was selected, and direct interventions were carried out regarding the replacement of existing bulbs in the building by other more efficient ones available in the market and accompanied by the monitoring of energy bills, to verify the reduction of 10 to $15 \%$ in the consumption of electric energy.

For the field research, the activities carried out were: visit to the selected building; collection of information necessary for the characterization of the building; contacts with the governmental body responsible for the education sector for the choice of municipal school; price and information verification to budget the interventions in the teaching unit; and studies related to reduce energy consumption.

In this way, in the studies carried out, it was verified that among the main possibilities to be used in efficient lighting systems are: electronic lamps (LED); presence sensors; energy management system for digital control; reactors; and luminaires. For this, the lamps must have Procel Class A Seal and the luminaires manufactured with technology that allows the maximum reflection of the light.

Thus, to investigate some possible strategies, it was initially considered the implantation of presence sensors in the bathrooms, together with the replacement of lamps in some classrooms in order to guarantee the reduction proposed in the study. However, the probing of the presence sensor installation was discarded after noticing on the visit carried out the existence of sensors already installed in the school bathrooms.

In the study to replace lamps, it was necessary to evaluate their equivalence, according to the verification of the norms pertinent to light comfort. The types of lamps were indicated considering the type of activity to be developed in the environment. Thus, in addition to the technical specifications of equipment and technologies used in lighting systems, light flux, illuminance, color temperature, color reproduction index, luminous efficiency, service life and median life were considered in this study.

To promote the actions of environmental education, lectures were given to the agents involved to boost the consumption of conscious energy in the public building of education and to present strategies of reduction in waste and energy saving that can be applied in the day to day. To involve everyone in the need to optimize responsible consumption. It is worth mentioning that the actions of environmental education resulted in three lectures of two hours each that had as target group students with age group between six and sixty years, besides employees and teachers.

In general, the content was provided information on the maintenance of renewable and non-renewable energy sources, as well as other topics that stimulate knowledge about energy efficiency. In addition to the correct use of air conditioners, lighting, and electronic equipment (computers, televisions, printers and others). In the actions were adopted playful 
methodologies to involve the children, and the adults a more informal language besides presenting the partial results of the PEEEPG project (monitored between the period from November 2016 to February 2017).

\section{Results}

The strategies used to reduce energy consumption were based on: (1) replacement of lighting elements; and (2) environmental education actions. The lighting of the building was based on the use of fluorescent lamps (compact and tubular) and incandescent lamps installed according to the need of the place.

From the actions taken and changes in the lamps: 52 fluorescent tubes $40 \mathrm{~W}, 8$ incandescent bulbs $60 \mathrm{~W}$ and 2 fluorescent bulbs $40 \mathrm{~W}$ and reactors $15 \mathrm{~W}$ by the system of LED lamps with $18 \mathrm{~W}$ and $10 \mathrm{~W}$. There was a reduction of $16 \%$ of the consumption of electricity, monitored for six months and evaluated in comparison to the consumption of the previous year. Approximately US\$850.00 was invested to replace bulbs and developed activities.

\subsection{Lamp Replacement}

The school's energy consumption is considered high compared to other schools of the same category. It was found that in part of the lighting system, $60 \mathrm{~W}$ incandescent bulbs, already banned from the market, were still used.

For practical intervention in the building, the study was limited to three classrooms of the 1st floor and external area (corridor) of which the classrooms, named according to the school of "room 8", "room 9" and "room 10". To obtain the equivalence of the lamps to be replaced, studies by Sousa (2016) were necessary. In this way, the replacement of the lamps was based on norms pertinent to light comfort. The Photograph 1 illustrates the classroom block where the interventions took place.

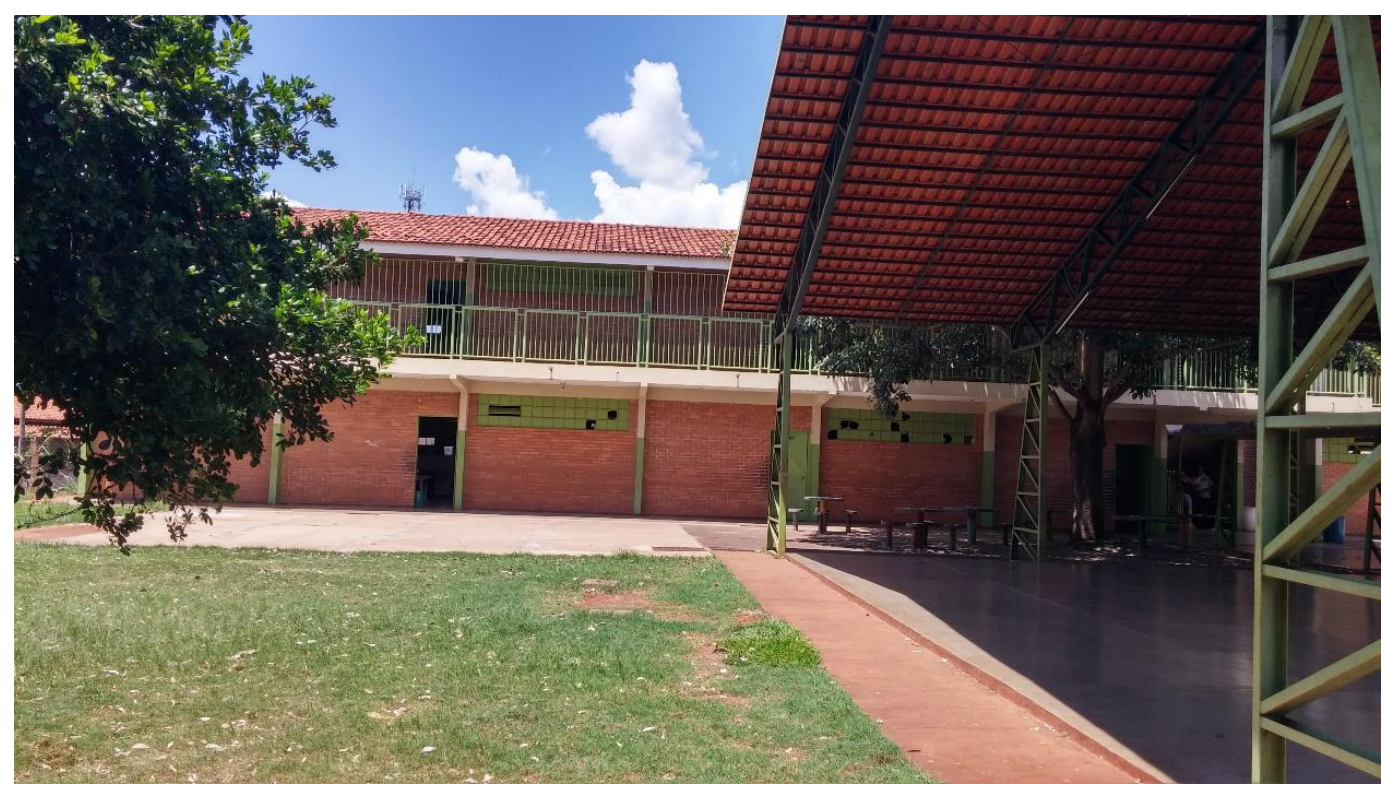

Photograph 1. Block of classrooms where the study was carried out in the public building of teaching. 
From the visits realized the bulbs were limited by the study and contacted to the hall and the classrooms. There were 8 incandescent bulbs $(60 \mathrm{~W})$ and 2 tubular fluorescent bulbs $(40 \mathrm{~W})$ in the block corridor. Which have been replaced by bulbs LEDs of bulb of $10 \mathrm{~W}$ and protected with grids against losses. The Photographs 2 and 3 illustrates the lighting system before and after the interventions, respectively. And in each classroom after conducting equivalence studies along with the regulations and notes of the manufacturers, the 18 existing $40 \mathrm{~W}$ fluorescent tube lamps were replaced by 14 tubular $18 \mathrm{~W}$ LED lamps. The Photographs 4 and 5 shows the changes made.

\subsection{Actions in Environmental Education}

The environmental education actions were built together with the coordination team in partnership with officials and teachers of the public education unit. Altogether, the project directly mobilized 200 people (students and employees) and indirectly 800 people among different age groups. To promote this stage, the activities were divided into two days (29 March 2017 and 17 April 2017), and the first day was the talk and activities with the students of the Youth and Adult Education (EJA), teachers and night staff. The presentation was technical-informative with the objective of boosting the consumption of conscious energy in the public building and publicizing the results achieved with the lamp replacements.

Possible strategies of collective responsibility for the reduction of electric energy, energy efficiency and wastes that can be applied in the school day-to-day and other places such as: using the maximum of natural light, giving preference to more efficient equipment available in the market and with lower energy consumption, among others. The Photograph 6 and 7 demonstrate the practices developed with the EJA audience in the school gymnasium.

To provoke the public regarding the responsibility of conscious use of electric energy, an activity was applied that points the profile of the consumers. In this exercise it was necessary to point out the behaviors before the scenarios presented in the day to day. And as a result, of the 51 fiches delivered, 32 students were diagnosed as responsible consumers. Followed by 11 students in the attentive user profile, 7 students as distracted users and 1 student with high wastage. Through this activity, it is concluded that it is possible to diagnose and apply individual/collective strategies, to foster the education of participants who have failed to reach the profile of responsible consumers.

On the second day (3 April 2017), in the morning the activities were aimed at children from 9 to 11 years old with the presence of 96 children, and in the afternoon counted on 30 children from 5 to 6 years old. The Photograph 8 presents the moment in the morning.

To have better attention of the children, the content of the lecture (in theater) counted on the use of animations in the form of videos, drawings and children's games with characters that children like and identify, addressing the conscious consumption and the minimization of waste of electricity. So, it met the expectations due to the participation and involvement of the children during the topics presented. In addition, other activities took place, such as: the application of "crossbones", coloring activities, adhesive bonding by students in classrooms with instructions for saving electric energy, and a satisfaction questionnaire relating the evaluation of the activities developed together to the formation of knowledge and adoption of new behaviors to help take care of the school.

The results of this activity were highlighted by the children's satisfaction in participating in the activities, as well as the contribution of new information. In general, the children who participated in the activities demonstrated their involvement in the dynamics presented and the responsibility to adopt practices for saving electricity in their school and other places. 


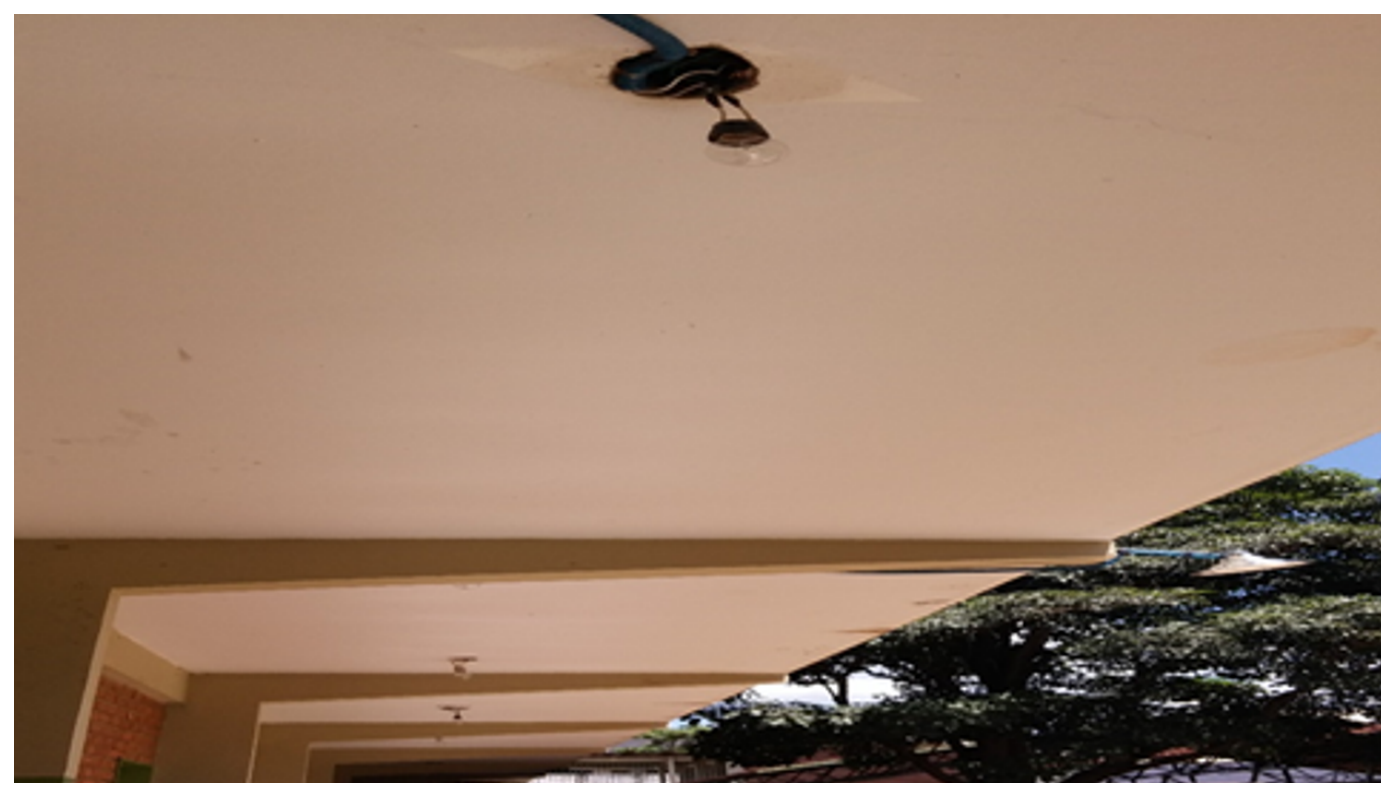

Photograph 2. Lighting system located in the corridor of the classroom block, prior to the intervention.

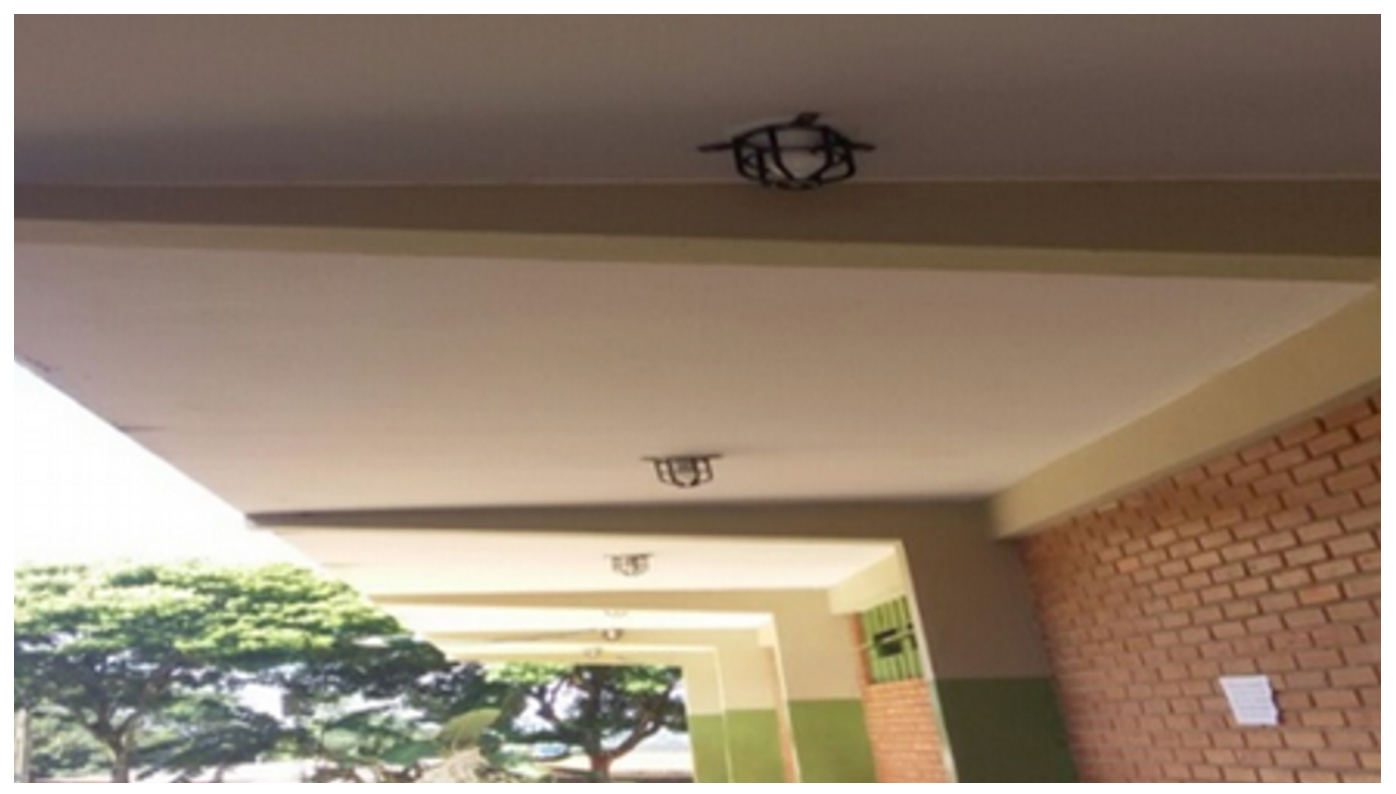

Photograph 3. Lighting system located in the corridor of the classroom block, after the intervention. 


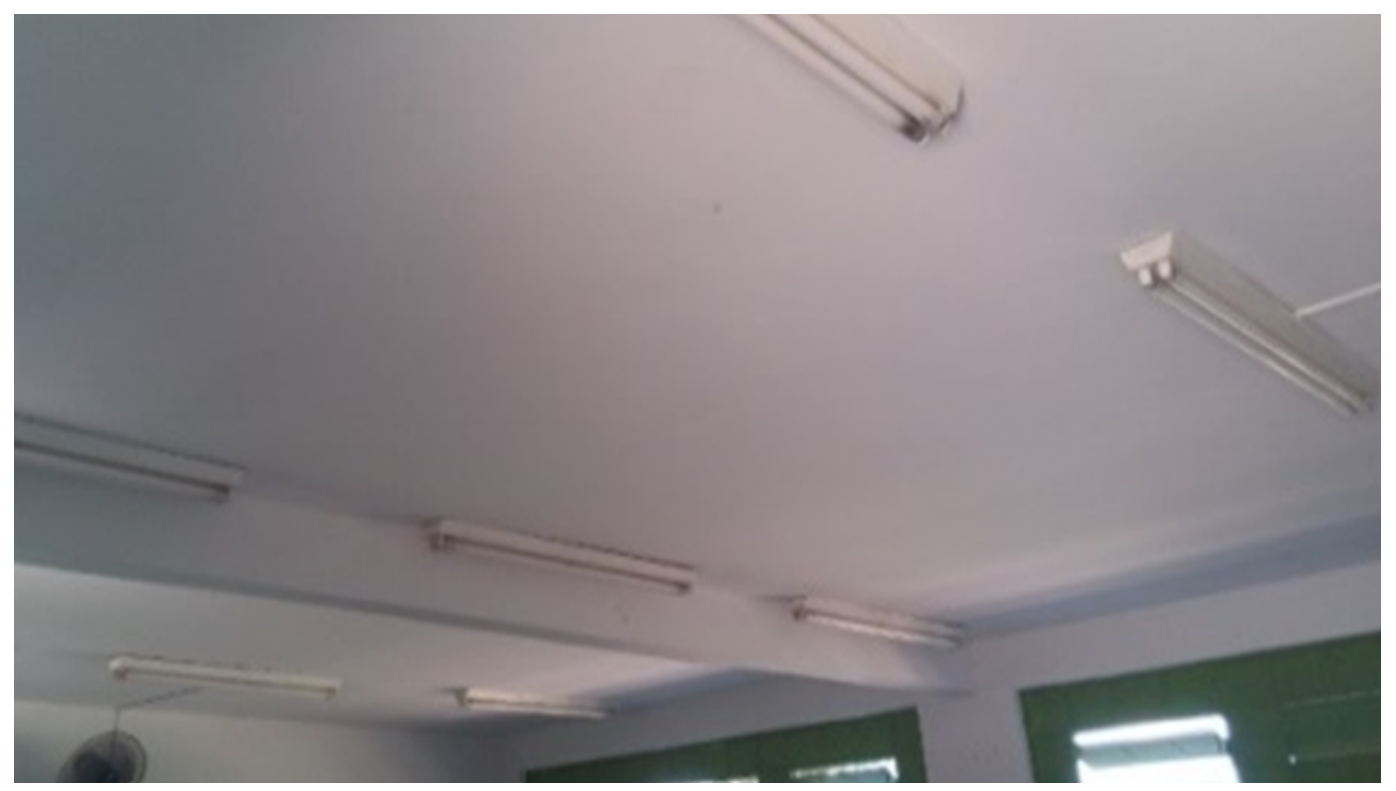

Photograph 4. Previous situation in the classroom.

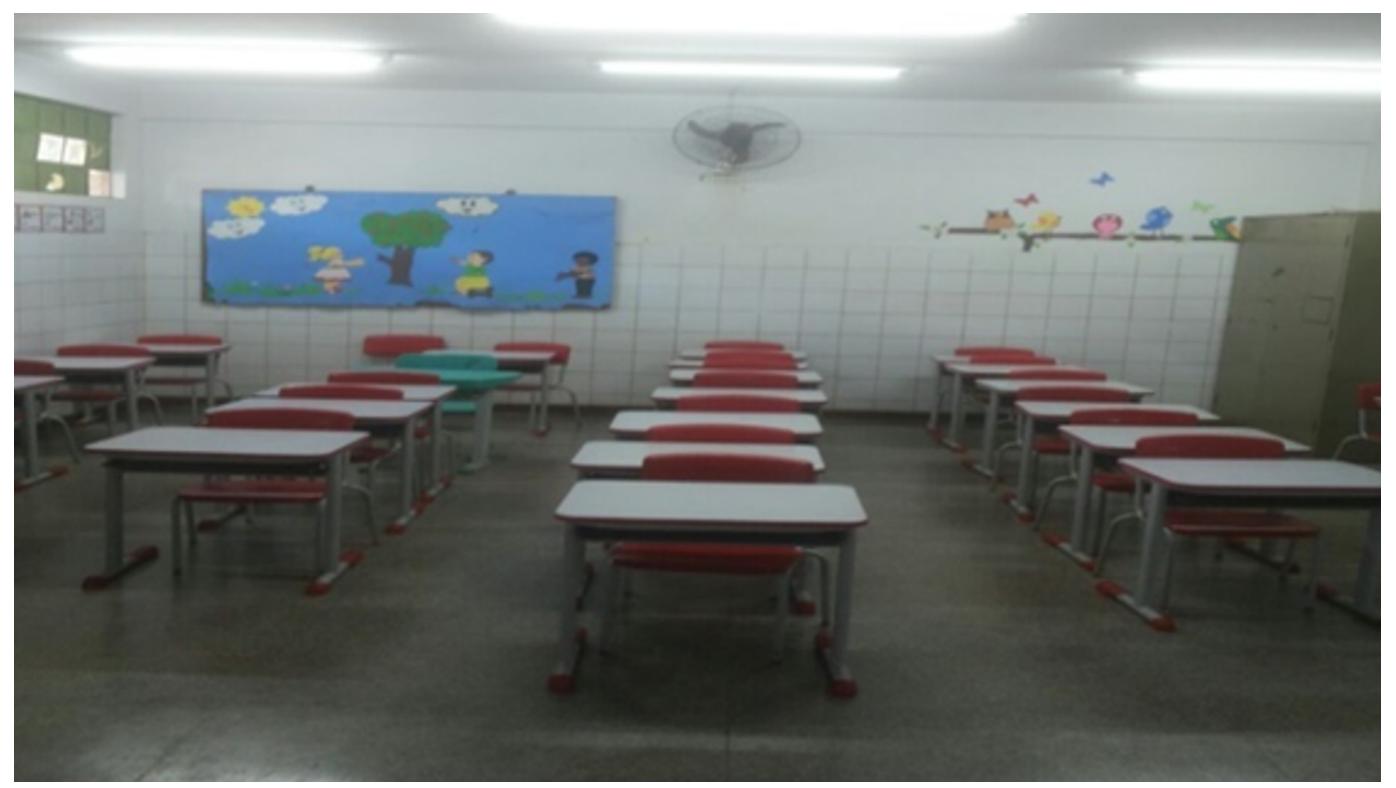

Photograph 5. Situation of the classroom after the changes. 


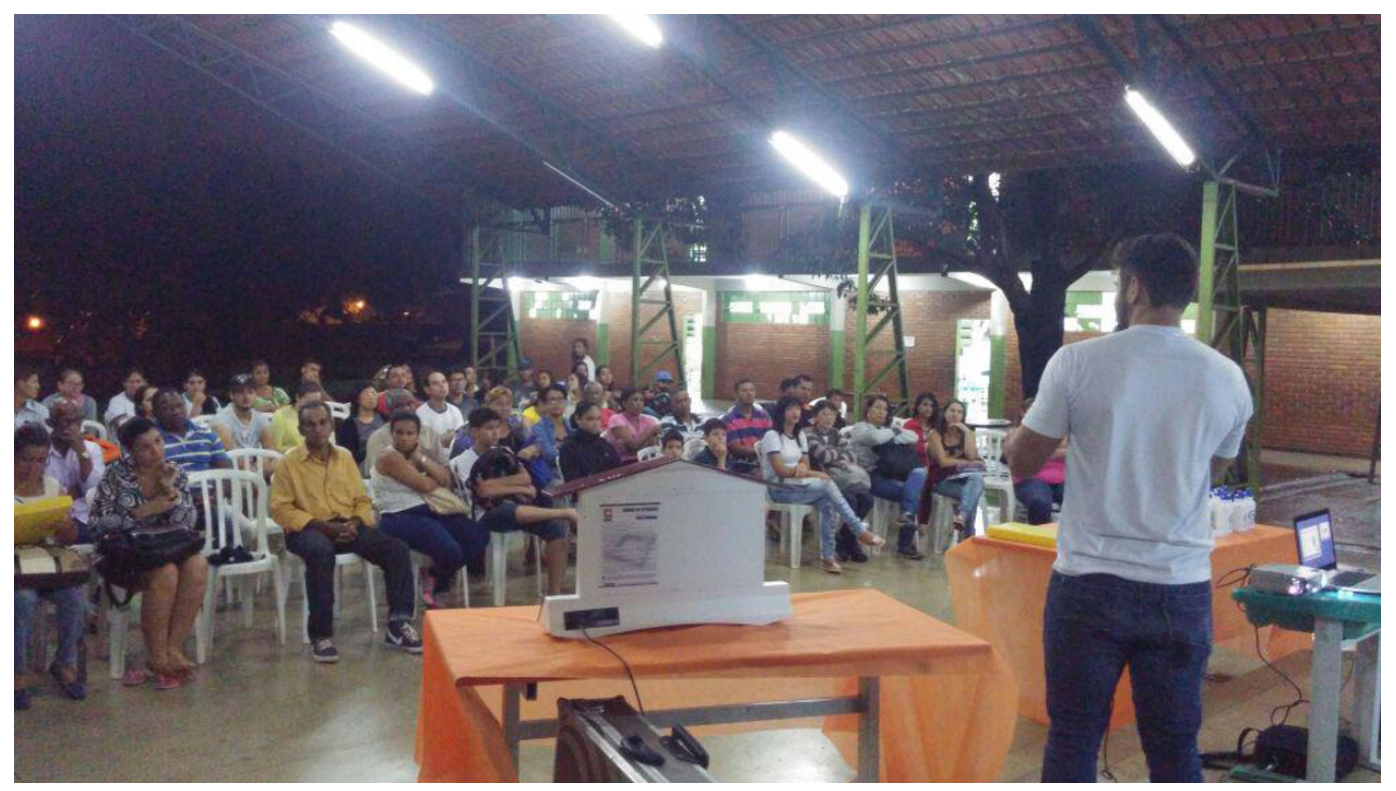

Photograph 6. Environmental education action with the public of the EJA.

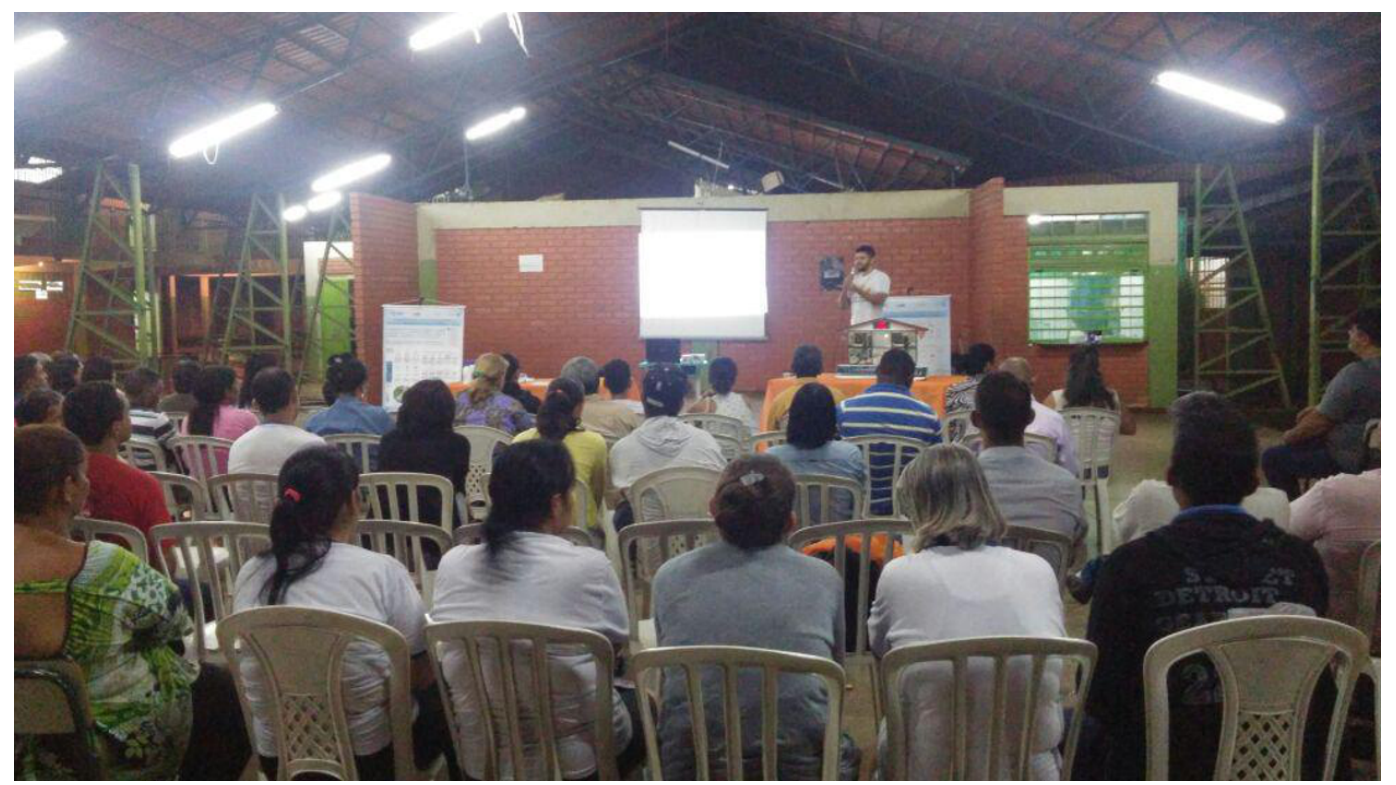

Photograph 7. Overview of space used in school. 


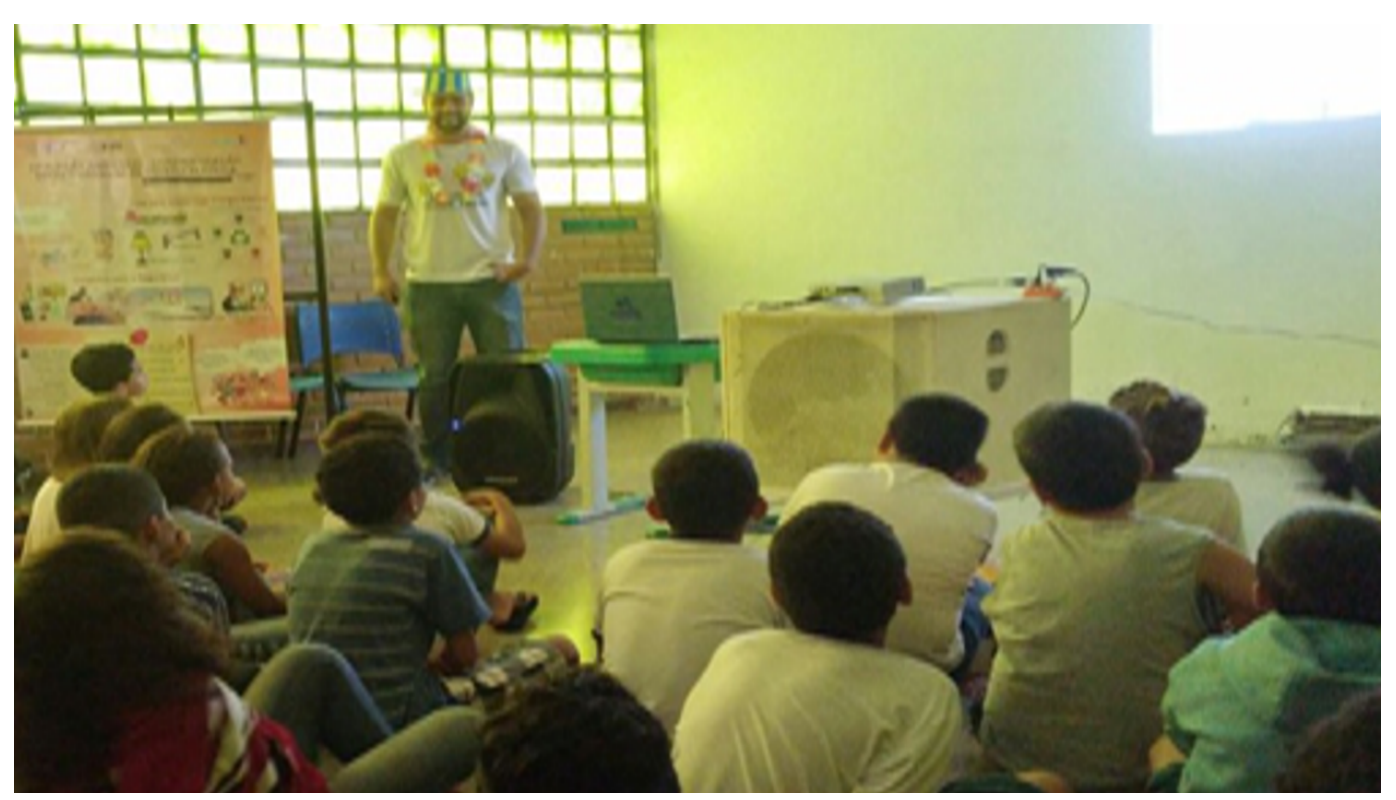

Photograph 8. Environmental education action with the public from 9 to 11 years old.

The materials used were donated to the school after the accomplishment of the activities, among: banners, stickers and personalized t-shirt. In addition, the strategy of distributing gifts for children and adults in all events was used as part of group activities.

The results evidenced the satisfaction of the young adults and children in participating in the activities, as evidenced by the completion of a satisfaction form, in addition to the contribution of new information. In general, both adults and children participating in the activities have demonstrated notions about the need to adopt responsible practices for saving electricity at their school and elsewhere. Despite this, only half of the young-adult students portrayed the application of energy conservation knowledge in their daily lives.

Next, the results obtained during the monitoring period realized with the lamp changes between November 2016 and April 2017 are presented, knowing that the results of the actions in environmental education had influence only for the months of March and April of 2017.

\subsection{Monitoring and Evaluation of Applied Strategies for Reducing Energy Consumption}

The energy consumption in the evaluated building is generally characterized by the lighting system and the use of basic equipment (computers, fans, televisions and others) and air conditioning (restricted to administrative areas). The bathrooms have compact fluorescents with activation through presence sensors which minimized the proposed reduction of energy consumption of the building.

The monitoring period after the interventions carried out lasted six months, covering November 2016 to April 2017. This monitoring was carried out based on the analysis of the energy consumption invoices issued by the energy concessionaire and made available by the Secretaria Municipal de Educação (SME). In this period, it was possible to observe an average reduction of $16 \%$ in the consumption of electric energy ${ }^{16}$, meeting the expectations 
initially proposed in the study, which were to reduce the electric energy consumption of the building from 10 to $15 \%$.

It should be noted that due to budgetary constraints, the interventions covered the building partially. The results indicated the existence of two behaviors: in the first moment a gain in the reduction of consumption and in the last two months a decrease that contradicts the trend obtained initially. Graphic 1 shows the data that served as a basis for comparison with the values obtained with the actions performed in the building.

The percentage verified in consumption in kWh beteween in the months of March and April, July and August can be justified by the number of hours of use of the equipment and the installation of new equipment during the period of monitoring or factors such as absence of operation of the building. This allows us to identify that due to fluctuations in the reduction percentage, it would be advisable to extend the follow-up period to obtain more conclusive results.

At the same time, the analyzed data allowed to define also the monthly and annual consumption of the building in $\mathrm{kWh}$. Being verified between the years of 2012 to $2014 \mathrm{a}$ $32.6 \%$ increase in the consumption of electric energy. Thus, a different scenario is observed, when the years between 2014 and 2016 are verified, a reduction of $33.86 \%$ is observed, as reported in Graphic 2.

Considering the data collection of the last years it was possible to identify the decrease in consumption. It is important to point out that the consumption of electricity is directly related to the number and hours of use of the equipment installed in a given period.

The Graphic 3 shows the consumption and electricity in the building monthly in the period from 2012 to 2016, and the values are shown in the Table 2.

It should also be noted that the consumption bill in $\mathrm{kWh}$ is related to the previous month, and consumption in January, February and August refers to the holiday periods. In addition, the results obtained allow us to identify that the periods with the highest energy expenditure can be justified to periods of critical climate in extreme temperatures, directly related to the consumption of electric energy in the building. An example of this can be seen in the consumption of the months of September and October, where the climatic conditions of the municipality reach high temperature levels and low values of air humidity, directly reflecting, for example, the increase in the consumption of electric energy with the use of refrigerators, fans, humidifiers to ensure the thermal comfort of building users. 


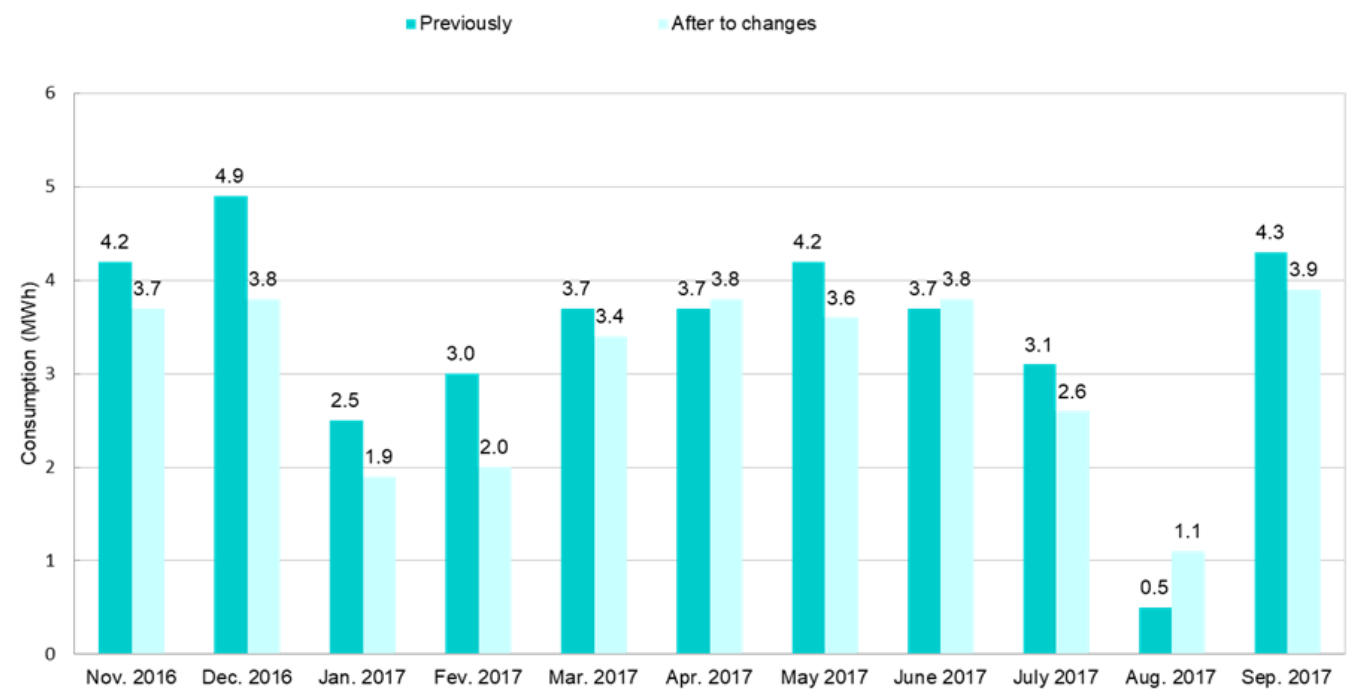

Graphic 1. Reduction in consumption compared to previous year's reading ${ }^{12}$.

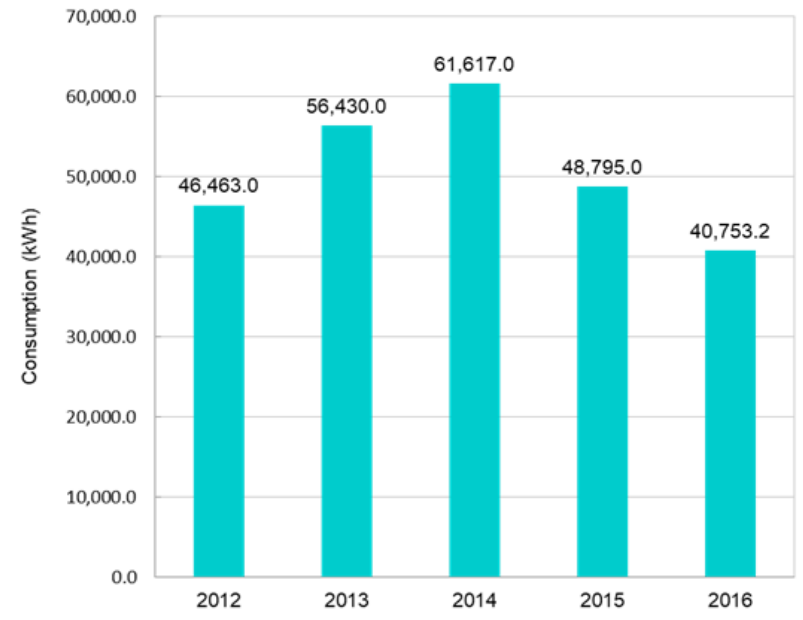

Graphic 2. Annual electricity consumption of the building in $\mathrm{kWh}^{12}$. 


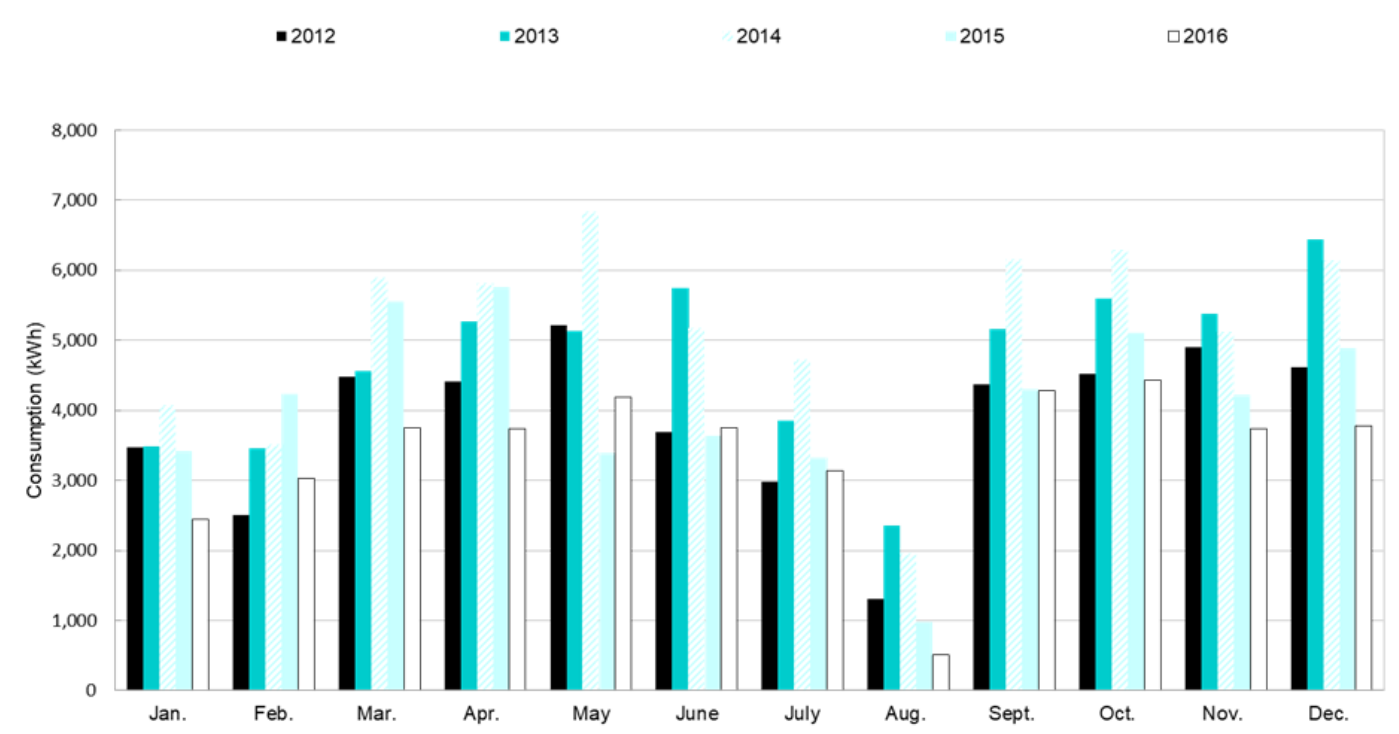

Graphic 3. Monthly electricity consumption of the building in $\mathrm{kWh}^{12}$.

Table 2. Monthly data the electricity consumption of the building in $\mathrm{kWh}^{12}$.

\begin{tabular}{|c|c|c|c|c|c|}
\hline Year/Month & 2012 & 2013 & 2014 & 2015 & 2016 \\
\hline January & 3,477 & 3,479 & 4,059 & 3,421 & 2,449 \\
\hline February & 2,510 & 3,458 & 3,509 & 4,234 & 3,034 \\
\hline March & 4,479 & 4,567 & 5,892 & 5,553 & 3,746 \\
\hline April & 4,407 & 5,264 & 5,808 & 5,758 & 3,735 \\
\hline May & 5,217 & 5,127 & 6,828 & 3,388 & 4,184 \\
\hline June & 3,690 & 5,742 & 5,173 & 3,636 & 3,747 \\
\hline July & 2,976 & 3,859 & 4,720 & 3,322 & 3,132 \\
\hline August & 1,303 & 2,352 & 1,954 & 980 & 510 \\
\hline September & 4,373 & 5,163 & 6,146 & 4,301 & 4,278 \\
\hline October & 4,521 & 5,599 & 6,283 & 5,100 & 4,431 \\
\hline November & 4,896 & 5,382 & 5,114 & 4,218 & 3,737 \\
\hline December & 4,614 & 6,438 & 6,131 & 4,884 & 3,771 \\
\hline Annual Consumption & 46,463 & 56,430 & 61,617 & 48,795 & 40,753 \\
\hline
\end{tabular}




\section{Conclusions}

After performing the environmental education actions and lamp changes by LED luminaires in three classrooms and block corridor, the monitoring carried out between six months of the year 2017 indicated a reduction of $16 \%$ in the total energy consumption of the building compared to last year ${ }^{17}$.

The environmental education actions carried out with the students of the school emphasized the importance of linking the social side with environmental issues, regarding the saving of electricity in public buildings, improving the daily bond between students, employees and teachers. Also, the relevance of performing such activities in the educational context was verified in these activities, given the enthusiasm shown by the participating students.

In view of the above, it should be noted that the activities developed had the good involvement and satisfaction of the students and school staff. It is hoped that such results can be used by municipal public administration, subsidizing project actions in energy efficiency and/or environmental education in the public sphere, retrofit and maintenance of public buildings, stimulating the public power to adopt normative instructions for this purpose.

Finally, from the closing of the activities, all those involved expressed interest in behavioral improvements and preservation of natural resources in the expectation of minimizing the effects that man's actions have on nature and ensuring a balanced and quality environment for the current and future generations.

\section{Acknowledgment}

We would like to thank the authors for the execution of this work and partnership between the International University of Florida and the Fundação de Apoio à Pesquisa (FUNAPE) through the project "Energy Efficiency in Municipal Public Buildings of Goiânia" that supported the accomplishment of this work.

\section{Reference}

1. MENKES, M. Eficiência Energética, Políticas Públicas e Sustentabilidade. Brasília: 2004.

2. BRANCO, S. M. Energia e meio ambiente. São Paulo: Moderna, 1990.

3. CAMACHO, M. A. da G. Modelo para Implantação e Acompanhamento de Programa Corporativo de Gestão de Energia. (M.Sc. Dissertation in Electrical Engineering)-Universidade Federal de Campina Grande, Campina Grande, 2009.

4. GARCIA, A. G. P. Leilão de Eficiência Energética no Brasil. 2008. 186 p. (Ph.D. Dissertation in Electrical Engineering)-Universidade Federal do Rio de Janeiro, Rio de Janeiro, 2008.

5. TOLMASQUIM, M. T. Perspectivas e planejamento do setor energético no Brasil. Estudos avançados, São Paulo, v. 26, n. 74, p. 249-260. 2012.

6. LAMBERTS, R.; DUTRA, L.; PEREIRA, F. O. R. Eficiência energética na arquitetura. São Paulo: PW Editores, 2014.

7. EMPRESA DE PESQUISA ENERGÉTICA. Balanço Energético Nacional 201\%: Ano base 2016. Empresa de Pesquisa Energética (EPE), Rio de Janeiro, ano XI, $\mathrm{n}^{\circ}$ 123, 2017. Available in: <http://epe.gov.br/pt/publicacoes-dados-abertos/publicacoes/resenha-mensal-do-mercadode-energia-eletrica $>$. Accessed on: 10 Dec. 2017.

8. SOUZA, H. et al. Reflexões Sobre os Principais Programas em Eficiência Energética Existentes No Brasil. Revista Brasileira de Energia, Rio de Janeiro, v. 15, n. 1, p. 7-26, 2009. 
9. PROGRAMA NACIONAL DE CONSERVAÇÃO DE ENERGIA ELÉTRICA. Relatório de resultados do Procel 2016 - ano base 2015. Programa Nacional de Conservação de Energia Elétrica (PROCEL), Rio de Janeiro, 2016.

10. EMPRESA DE PESQUISA ENERGÉTICA. Resenha Mensal do Mercado de Energia Elétrica. Empresa de Pesquisa Energética (EPE), Rio de Janeiro, ano IX, $\mathrm{n}^{\circ}$ 100, 2016. Available in: <http://epe.gov.br/pt/publicacoes-dados-abertos/publicacoes/resenha-mensal-do-mercadode-energia-eletrica $>$. Accessed on: 10 Dec. 2017.

11. DIDONE, E. L.; WAGNER, A.; PEREIRA, F. O. R. Estratégias para edifícios de escritórios energia zero no Brasil com ênfase em BIPV. Ambiente Construído, Porto Alegre, v. 14, n. 3, p. 27-42, 2014

12. CELG DiSTRIBUIÇÃO. Portal da Celg Distribuição (Celg-D). Available in: $<$ https://www.celg.com.br/>. Accessed on: 17 Apr. 2016.

13. INSTITUTO BRASILEIRO DE GEOGRAFIA E ESTATÍSTICA. Portal do Instituto Brasileiro de Geograifa e Estatística (IBGE). Available in: <http://www.ibge.gov.br/>. Accessed on: 02 Jul. 2016.

14. HORA, K. et al. Eficiência energética de edifícios públicos em Goiânia. Universidade Federal de Goiás (UFG), Goiânia, Relatórios Técnicos, 2015.

15. DEMO, P. Metodologia científica em Ciências Sociais. São Paulo: Atlas, 1995.

16. ROSA, M. N. et al. Environmental Education as A Strategy to Reduce Electric Energy Consumption: An Approach at A Municipal School in Goiânia, Goiás, Brazil. In: INTERNATIONAL CONFERENCE ON ALIVE ENGINNERING EDUCATION, 2018, Puerto Iguazú. Electronic Proceedings... Goiânia: Gráfica UFG, 2018. p. 79-80. Available in: $<$ https://icaeedu.emc.ufg.br/p/27041-icaeedu-2018-publications >. Accessed on: 12 Mar. 2019.

17. ROSA, M. N. et al. Environmental Education as A Strategy to Reduce Electric Energy Consumption: An Approach at A Municipal School in Goiânia, Goiás, Brazil. In: DEUS JUNIOR, G. A. de et. al. (Org.). Alive Engineering Education: Integrating and Innovating Engineering Education in Favor of Society. Goiânia: Gráfica UFG, 2019. cap. 37, p. 389-400. Available in: <https://icaeedu.emc.ufg.br/p/27041-icaeedu-2018-publications >. Accessed on: 12 Mar. 2019. 
